\title{
Effects of Amendments in Nitrogen, Phosphorus, Potassium, Zinc and Gypsum on the Quality of the Rice Grain, in Salinity Conditions
}

\section{Tala Gueye ${ }^{1}$, Khadidiatou Ndoye Ndoye Ndir ${ }^{1}$, Amadou Oury Diallo², Karim Traoré ${ }^{3}$}

\author{
${ }^{1}$ Ecole Nationale Superieure d'Agriculture (ENSA) \\ ${ }^{2}$ Societe Nationale d'Amenagement des Eaux du Delta (SAED), Saint - Louis, Senegal \\ ${ }^{3}$ Africa Rice Centre (AfricaRice), Ndiaye, Saint-Louis, Senegal
}

\begin{abstract}
This study is to investigate the effects of the amendments in macronutrients nitrogen-phosphatepotassium (NPK) and microelements zinc and gypsum on physicochemical qualities of rice grain. The design is a split plot with two factors: fertility with 12 levels of fertilizers and variety with 6 rice varieties, repeated in 3 blocks, in two different media, including a salty medium (MS) and a unsalted medium (MNS). Six (6) rice varieties were used, of which four (4) tolerant varieties, and two (2) controls varieties that are moderately sensitive and very sensitive respectively. Results show a total yield milled grain of tolerant varieties, highest in saltwater environments as in unsalted middle, while the opposite effect is observed with susceptible varieties. The highest yields milled total grains were observed in a saltwater medium, with the formula 120-26-50 with or without zinc or Gypsum. In unsalted medium, it is the formula 0-26-50 with or without zinc or gypsum, which gives the best yields total milled grains. Broken grains have best performance in a saltwater environment, whatever variety or combination of fertilizer used. Weight of 100 grains is more efficient in unsalted environment, whatever variety or combination of fertilizer used. Depending on the alkaline spreading value (ASV), varieties can be divided into two groups. Varieties of the first group with low AVS ( 3 to 4 ) have a gelatinization temperature (GT) intermediate. Those in the second group, with a middle and higher AVS (5.4 to 6), have low gelatinization temperature. The varieties of this last group with low GT, are more interesting for the market and consumers because they require only a low cooking time.
\end{abstract}

Keywords: irrigated rice, grain yield, quality, Salinity, fertilization, alkaline spread value (ASV), gelatinization temperature (GT).

\begin{abstract}
Introduction
Rice is one of the major cereal that is the staple food of nearly a third of the world population (Zhao et al., 2011). It is produced in about 110 countries, including most countries in West Africa. Most of the rice consumed in Senegal is imported from Asian countries with a consumption of $90 \mathrm{~kg}$ per capita (FAO, 2012). Low rice production at the national level, significantly lower than the demand and marketing difficulties related to product quality have long limited the competitiveness of locally produced rice. After the yield, grain quality is the most important factor considered by breeders and consummers to achieve self sufficiency in rice (Juliano and Duff, 1991). One of the current challenges for a country that wants to emerge is to use precision agriculture to reduce the problems
\end{abstract}

related to food insecurity and meet the future needs of the population, while preserving a healthy environment. However, abiotic stresses such as soil salinity is a major constraint for the environment but above all for the sustainable improvement of the quality of the rice grain, and yields in whole grains. Many authors of which Alam et al. (2009) have shown that a judicious and appropriate use of fertilizers can increase yields and improve the quality of rice. In fact, fertilizers are factors of intensification of production systems, whose profitability depends largely on the quality of fertilizers used (Tabar 2012). To overcome this constraint, which impacts negatively on the development of rice farming, various research has been initiated to create rice varieties tolerant to salinity (Bimpong et al, 2016) as well as many combinations of fertilizers to optimize

This article is published under the terms of the Creative Commons Attribution License 4.0

Author(s) retain the copyright of this article. Publication rights with Alkhaer Publications.

Published at: http://www.ijsciences.com/pub/issue/2016-12/

DOI: 10.18483/ijSci.1172; Online ISSN: 2305-3925; Print ISSN: 2410-4477 
production in both normal and saline conditions. However, grain yield generally being the final objective, it is also important to study if fertilizer inputs has an impact or not on the quality of the rice grain. It is in this perspective that this study was initiated. The main objective is to analyze the influence of various chemical fertilizers on the quality of the rice grain. More specifically, this study aims to (i) compare the effects of NPK, alone or combined with zinc or gypsum, the physicochemical characteristics of the rice grain, and (ii) to identify the best fertilizer formula under conditions of salinity.

\section{Material and methods}

Area description

This study was conducted at the experimental station of the Africa Rice Center (AfricaRice), based in Ndiaye, $35 \mathrm{~km}$ from Saint-Louis, in the Delta of the Senegal River Valley. The study was conducted during the hot dry season in two different media, including a unsalted medium (MNS), containing freshwater, and saltwater medium (MS).

\section{Evolution of the Electrical Conductivity (EC)}

The first measurement was made at transplanting seedlings whose seeds were sown three weeks previously in nurseries. During the experiment, the electrical conductivity remained high in salt medium between $4 \mathrm{dS} / \mathrm{m}$ and $8.5 \mathrm{dS} / \mathrm{m}$. In unsalted medium by against, it remained low with values less than $1 \mathrm{dS}$ / $\mathrm{m}$ (Figure 1). We note that over time, the EC decreases when rice is grown in a saltwater environment.

\section{Plant Material}

The plant material is composed of six rice varieties including 2 controls as Sahel 108 and IR 31785, which are respectively medium and high saltsensitive and four tolerant varieties like IR 4630-222-5-1-3, IR 59418- 7B-21-3, IR-76346 BB-10-1-1-1, IR-72 593 B-3-2-3-8 (Table 1). Sahel 108 was the local variety released in Senegal and well appreciated by farmers. Other varieties are introduced and are in the testing phase.

\section{fertilizers}

Twelve (12) Mineral fertilizer levels combining elements N-P-K and optional zinc or gypsum were applied at different doses (Table 2). For fertilization, nitrogen inputs with $60 \mathrm{~kg} / \mathrm{ha}, 120 \mathrm{~kg} / \mathrm{ha}$ and 150 $\mathrm{kg} / \mathrm{ha}$ as urea have been divided in 3 successive applications made to early tillering stage, the stage of panicle initiation and 10 days before flowering. The others fertilizers were introduced in one portion as basal dressing with $26 \mathrm{~kg} / \mathrm{ha}$ of $\mathrm{P}$ as triple super phosphate (TSP), $50 \mathrm{~kg} / \mathrm{ha}$ of $\mathrm{K}$ as $\mathrm{KCl}, 10 \mathrm{~kg} / \mathrm{ha}$ of $\mathrm{Zn}$ under form of zinc sulfate and $100 \mathrm{~kg} / \mathrm{ha}$ of gypsum

\section{Experimental design}

The experimental design is a two-factor split plot with 3 repetitions and 2 environments. The main factor is composed of 12 levels of fertilizer and the secondary factor is represented by 6 rice varieties. The study was conducted in two different media with a salt medium (MS) with a salinity level $\geq 3 \mathrm{dS} / \mathrm{m}$, and a unsalted medium (MNS) using freshwater.

The trial was set up in large plots or sub-blocks of $50.1 \mathrm{~m} 2$ and small plots or sub plots of $8 \mathrm{~m} 2$. The main plots were separated by wide bunds to minimize lateral percolation of water between two plots. The layout of the unit plot is illustrated in Figure 2.

\section{Parameters studied}

\section{Humidity}

A small amount of each sample of $125 \mathrm{~g}$ of clean paddy will be used to measure the moisture content that will enable calculating the paddy weight adjusted to $14 \%$ which is the weight of paddy used brought to a moisture content of $14 \%$ according to the following relationship:

$$
\text { Weight adjusted to } 14 \%=\frac{(100-\text { Moisture read rate })}{(100-14)} \times \text { Sample weight }
$$

Grain size (paddy and brown rice)

This is the length and the width of the grain. They are measured on 10 grains of paddy and brown rice. The length to width ratio gives the shape of the grain. A scale of rice grains classification according to their form is given by the Standard Evaluation System (IRRI, 1980) (Table 3).

Yield after processing

It is obtained by the following report:

Percentage of whole grains

$$
\% \text { Yield after processing }=\left(\frac{\text { Total weight milled rice }}{\text { Weight adjusted to } 14 \%}\right) \times 100
$$

It is determined by the ratio:

$$
\text { Whole grins } \%=\left(\frac{\text { Weight of } \text { whole grains }}{\text { Weight adjusted to } 14 \%}\right) \times 100
$$




\section{Percentage of broken grains}

It is obtained by the difference between the yield after processing and the percentage of whole grains:

$\%$ Borken grains

$$
\begin{aligned}
& =\% \text { Yield after processing } \\
& -\% \text { Whole grains }
\end{aligned}
$$

Weight of 100 grains of paddy

It is obtained by simple weighing. But these 100 grains must be properly chosen to be representative for each variety.

\section{Gelatinization temperature (GT)}

Gelatinization temperature of the starch is a parameter assessed using a test called alkaline test or test ASV "Alkali Spreading Value". The alkali test determines the energy needed for cooking and water absorption during cooking. More the alkali spread value is, the more the GT is high.

Whitened rice grains are steeped for 13 hours minimum in the alkaline solution, because of $6 \mathrm{good}$ grains (whole grain not moldy and not chalky) per petri dish containing $10 \mathrm{ml}$ of alkaline solution; the grains are arranged such that they do not touch (IRRI, 1996). The alkali spread value is a simple indicator. Note 2 is given to intact grains; 3 for whole grains with mild to moderate dispersion; 4 for the grains with collar surrounding the grain; 5 for severely scattered grains; 6 for the grains with the cottonshaped center and 7 for completely dissolved grains (Figure 9). The notation is visual and is based on the method of Jennings et al. (1979).

Statistical Analyses

Statistical analysis of the data was performed with the software "Statistical Analysis System" version 9 (SAS Institute, 2002). Furthermore, comparison of averages was carried through the Duncan test at the $1 \%$ and $5 \%$.

\section{Results}

Statistical analysis of data on physical and chemical characteristics of the rice grain

The results of the analysis of variance are given in Table 4.

It appears from the analysis of variance that there has a variety $\mathrm{x}$ fertilizer interaction only with the ASV parameter. For other parameters, there's no interaction and therefore the varieties and fertilizers can be analyzed separately. The variety does not affect fertilizer and vice versa. By against, with the alkali test (ASV), both treatments (fertilizers and varieties) are linked and any interpretation of one must take into account the other.

\section{Whitened total grain yield (\%)}

The results obtained with the fertilizer formulas are applicable for all varieties because there is no interaction variety $\mathrm{x}$ fertilizer.

For the characters studied in both salty medium (MS) and unsalted (MNS), the results show that there's a significant difference $(\mathrm{P}<5 \%)$ to highly significant between combinations of fertilizer. A highly significant difference $(\mathrm{P}<1 \%)$ also exists among varieties for all the variables studied (Table 4). In MS medium, the highest yield grain milled total $(65.94 \%)$ is obtained with the formula 120-26-50 fertilizer with or without zinc or gypsum while in MNS medium the best performance was obtained with the formula 025-50 with or without zinc or gypsum (Figure 3).

\section{Whole grain yield (\%)}

Analysis of variance showed a highly significant difference ( $\mathrm{P}<1 \%)$ between varieties in both media. In MS, it is the IR 4630-22-2-5-1-3 tolerant variety that has the best performance in whole grains with an average of $50.38 \%$, while in MNS is the tolerant variety IR 76346-BB -10-1-1-1 which presents the best performance with $59.69 \%$ (Figure $4 \mathrm{c}$ ). The lower yields of whole grain on both media were obtained with the highly susceptible variety IR 31785-58-1-23-3 with $33.99 \%$ and $43.48 \%$ respectively in MS and MNS (Figure 4c).

\section{Broken grain yield (\%)}

There is a highly significant difference $(\mathrm{P}<1 \%)$ between varieties for both environments. Between the fertilizer formulas, there is a significant difference $(\mathrm{P}$ $<5 \%$ ), in unsalted environments and a non-significant difference in salty environments (Table 4). Of all the varieties (Figure $4 \mathrm{c}$ and $4 \mathrm{~d} 1$ ), and combinations of fertilizers (Figure 4d2), the rate of broken grains is higher in salinity conditions than in freshwater conditions. Thus, salinity seems to favor yields broken grains.

\section{Weight of 100 grains of paddy rice $(\mathrm{g})$}

Between combinations of fertilizer, the weight of 100 grains is significant $(\mathrm{P}<5 \%)$ in MNS medium, and is highly significant $(\mathrm{P}<1 \%)$ in MS medium. Between varieties, this characteristic is highly significant ( $\mathrm{P}$ $<1 \%$ ) in both media (Table 5). Of all the varieties and combinations of fertilizers, weight of 100 grains is higher in non-saline environment, as in a saltwater environment (5e and 5f). The best rates were obtained with the formula 60-26-50, in a saltwater environment, and the formula 150-26-50 + gypsum in non-salty environment (Figure 5e).

\section{Grain shape}

In saltwater, the grain length was highly significant $(\mathrm{P}<1 \%)$ between varieties and between fertilizer formulas. In unsalted medium, this variable is also highly significant among varieties (Table 4). The length / width ratio $(\mathrm{L} / \mathrm{W})$ of the rice grains shows a highly significant difference $(\mathrm{P}<1 \%)$ between varieties on all media. 
Alkali spreading value (ASV)

The interaction variety and fertilizer formula $(\mathrm{G} * \mathrm{~N})$ for ASV variable present a significant difference in a saltwater environment. The average value of ASV for each variety was declined in Table 5. It is observed that varieties like Sahel 108, IR 31785-58-1-2-3-3, IR 4630-22-2-5-1-3, IR-59418-7B 21-3, and IR 72593B-3-2-3-8 show low ASV which varies very little according to the different combinations with values between 3 to 3.6, except for variety IR 72593-B-3-23-8 whose AVS value highly varies according to the fertilizer formulas, with value betweed 3 and 5.4. The gelatinization temperature (GT) of these varieties will be intermediate. In contrast, variety IR-B-76346 B10-1-1-1 has a high ASV which varies slightly according to different formulas with values between 5.5 and 6 . This means that this variety has a low gelatinization temperature. The highest ASV value was obtained with the formula 150-26-50+ Zn, while the lowest values of ASV were observed with nonfortified fertilizer formulas with zinc or gypsum. Depending on the value of the ASV, the varieties were classified into two groups with one group composed of low ASV varieties, which have a gelatinization temperature (GT) intermediate, and a second group, represented by one variety, with high ASV, which present a low gelatinization temperature (Figure 6).

\section{Discussions}

The objective of this study was to characterize the effect of mineral fertilizers reinforced with zinc or gypsum on the physicochemical characteristics of the grain of 6 varieties of rice in irrigated condition through two different media including a salt medium and not salted. The results showed better yields whitened grains in salted environment than unsalted environment. The 120-26-50 fertilizer formula is the combination of NPK recommended and vulgarised in the Senegal River valley. It gives the best performance in seeds, in unsalted environment. In saltwater environments complement gypsum improves grain yields. By cons, this additional contribution gypsum causes a drop in yield from $1.43 \%$ in environment unsalted. These results confirm those of Muhammed et al. (1986), and Xiong et al. (2008), which showed that gypsum intake promotes better tolerance of the plant to salt and that the nitrogen intake may increase the rate of milled rice. The results show better performance tolerant varieties in whole grains, both in salty environment than unsalted environment compared to susceptible varieties. These sensitive varieties develop rather more broken grains in both media, unlike the tolerant varieties, which show a lower breakage rate $(<25 \%)$. These results could be explained by the effect of the formula 150-26-50 + zinc on tolerant varieties, which have less broken rice which greatly increases the efficiency of the machining. These results corroborate those of Sartaj et al. (2001) and Dilday (1987), which show a negative correlation between rate and broken rice rate of whole grain in nitrogen deficiency condition. The best performance on the weight of 100 paddy rice grains were obtained from varieties 463022-2-5-1-3 IR and IR 72593-B-3-2-3-8 in a saltwater environment. The best weight 100 grain were obtained with the formula 60-26-50, in a saltwater environment and the formula 150-26-50 + gypsum in unsalted environment. This suggests a significant influence of the nitrogen factor on grain weight, particularly salinity conditions with gypsum addition. These results are similar with those Sartaj et al. (2001), which showed positive correlations between the thousand grain weight and the nitrogen supply, and those Rasouli et al. (2013), who showed an improvement of the weight of 100 grains of wheat with an addition of gypsum. In both environments, the ASV different varieties varies little from one medium to another. This is explained by the fact that the ASV is not affected by salt stress. The alkalinity distribution value and consistency of the gel are not affected by growing rice in saline soil (Siscar-Lee et al., 1990). Compared to the interaction varieties $x$ fertilizers, varieties Sahel 108 IR31785-58-1-2-3-3, IR4630-22-2-5-1-3, IR59418-7B-21-3, and IR72593B-3-2-3-8, have an average ASV with all combinations of fertilizer therefore their gelatinization temperature will be between 70 and 74 ○ C. Tolerant variety IR76346-BB-10-1-1-1 shows high ASV (between 5.5 and 6) with all combinations except for the formula 120-26-50 + gypsum, where there is an average ASV (3.72). The gelatinization temperature will be low and less than $70{ }^{\circ} \mathrm{C}$ for all combinations of fertilizer except for the formula 120$26-50+$ gypsum where the GT will be between 70 and $74^{\circ} \mathrm{C}$.

\section{Conclusion}

This study allowed to characterize the effect of mineral amendments on the quality of the rice grain. The various formulas tested showed effects on the physicochemical characteristics of the grain, as in MS MNS. The formula 120-26-50 with gypsum addition promotes an increase in total grain yield whitened in MS. This is an interesting result that helps mitigate the low yields of grain whitened in salinity condition. In environment unsalted, the formula 150-26-50 + Zinc promotes a reduction in the rate of broken grains of up to $10.94 \%$ compared to the results obtained in a saltwater environment. Variety IR76346-BB-10-1-11 with low gelatinization temperature is very promizing for consumer in the région according to deficit of energy in the région.

\section{References}

1) Alam MM, Hassanuzzaman $M$ and Nahar K. 2009.Tiller dynamics of three irrigated rice varieties under varying phosphorus levels. American -Eurasian Journal of Agronomy 
2(2):89-94.

2) Arraudeau M. 1998. Le riz irrigué. Agence de coopération culturelle et technique, Paris et Centre technique de coopération agricole (C.T.A.), Wageningen. Vol 2. 336p.

3) Asch F, Dingkuhn M and Dörffling K. 1993. Physiological stresses of irrigated rice caused by soil salinity in the Sahel. Irrigated rice in th Sahel: Prospect for sustainable developpement. Session 4: Stress environnementaux. ADRAO. Publication bilingue. p. 247-273.

4) Bahmanyar MA and Mashaee SS. 2010. Influences of nitrogen and potassium top dressing on yield and yield components as well as their accumulation in rice (Oryza sativa). African Journal of Biotechnology Vol. 9(18), pp. 2648-2653.

5) Barber S. 1972. Milled rice and changes during aging. In D.F. Houston, ed. Rice chemistry and technology, p. 215 263. St Paul, MN, USA, Am. Assoc. Cereal Chem.

6) Bimpong IK, Manneh B, Sock M, Diaw F, Amoah NKA, Ismail AM, Gregorio G, Singh RK, Wopereis M. 2016. Improving salt tolerance of lowland rice cultivar 'Rassi' through marker-aided backcross breeding in West Africa, Plant Science, Volume 242, Pages 288-299, ISSN 01689452.

7) Brown RS, Sander C and Argos P. 1985. The primary structure of transcription factor TFIIIA has 12 consecutive repeats. FEBS Lett. 186 (2): 271-4.

8) Cagampang GB, Cruz LJ, Espiritu SG, Santiago RG and Juliano BO. 1966. Studies on the extraction and composition of rice proteins. Cereal Chem. 43:145-155.

9) Cagampang GB, Perez CM and Juliano BO. 1973. A gel test for the eating quality of rice. J. Sci Food Agr. 24 : 15891594.

10) Chen L and Dick WA. 2011. Gypsum as an agricultural amendment: General Use Guidelines. The Ohio State University, USA. 36p.

11) Chopra NK and Chopra N. 2004. Effect of row spacing and nitrogen level on growth, yield and seed quality of scented rice (Oryza sativa) under transplanted conditions. Indian J. Agronomy, 45(2):304-308.

12) Courtois B. 1998. Les systèmes de culture du riz pluvial. Mémoires et Travaux de l'IRAT 16, 96p.

13) Courtois B. 2007. Une brève histoire de l'amélioration génétique du riz. Cirad, Montpellier Cedex 5, France. 13p.

14) Cruz JF et Matignon-Pons B. 2012. Plateforme technologie agroalimentaire. CIRAD.

15) De Datta SK. 1965. Phosphate availability and fertilizer Res.Inst. Thursday Seminar 2 Septembre 1965 Loss BanosPhilippines.

16) De Datta SK. 1981. Principles and practices of rice production. John Wiley and son. New york, 618p.

17) Dien LD, Trinh NB, Lieu LT and Hieu LH. 1987. Influence of seasons on several biochemical criteria of rice seeds (Oryza sativa L.). Tap Chi Sinh Hoc, 9(2): 15-21, 31

18) Dingkuhn M, Asch F and Miézan K. 1993. Salt tolerance of rice varieties under irrigated conditions in the Sahel. WARDA, Annuel Report 1992. 01 BP 2551 Bouake, Côte d'Ivoire.

19) Dilday RH. 1988. Effect of nitrogen fertilizer on milling quality of rice (oryza sativa). Proceedings Arkansas Academy of Science, Vol. 42.

20) Dobermann A and Fairhurst T. 2000.Rice: Nutrient Disorders and Nutrient Management, Potash and Phosphate. Institute of Canada, and International Rice Res, Institute, Los Banos, Philippines. 192p.
21) FAO. 2012. Aperçu du développement rizicole au Sénégal. APRAO. 10p.

22) Fageria NK. 1985. Salt tolerance of rice cultivars. Plant and soil, 88, 237-243.

23) FERTIAL, 2010. MANUEL : utilisation des engrais. Les fertilisant d'Algérie. 100p.

24) Flowers TJ and Yeo AR. 1981. Variability in the resistance to sodium chloride salinity within rice (Oriza sativa L.) varieties. New Phytol. 88, 363-373.

25) Flowers TJ and Yeo AR. 1989. Effects of salinity on plant growth and crop yield. J. H. Cherry (Ed), Environmental Stress in Plants (NATO ASI Series, Vol G19). Springer Verlag Berlin Heidelberg.

26) Hao H, Wei Y, Yang X, Feng $Y$ and Wu C. 2007. Effects of Different Nitrogen Fertilizer Levels on $\mathrm{Fe}, \mathrm{Mn}, \mathrm{Cu}$ and $\mathrm{Zn}$ Concentrations in Shoot and Grain Quality in Rice (Oryza sativa). China National Rice Research Institute. Rice Science, 2007, 14(4): 289-294

27) Huang JF. 1990. The relation between soil nutrients and rice qualities. Trans. 14th Int. Congr. Soil Sci., Kyoto, 12- 18 August. 4: 170175.

28) IRRI. 1964. Annual Report for 1963, pp. 149-161. The Institute: Los Baflos, Laguna, Philippines.

29) IRRI. 1996. Standard Evaluation System for rice. INGER Genetic Ressources Center. Manila, Philippines. 51p.

30) Juliano BO. 1971. A simplified assay for milled-rice amylose. Cereal Sci. Today $16: 334-340$.

31) Juliano B0. 1972. The rice caryopsis and its composition. In D.F. Houston, ed. Rice chemistry and technology, p. 1674. St Paul, MN, USA, Am. Assoc. Cereal Chem.

32) Juliano BO, ed. 1985b. Rice: chemistry and technology, 2nd ed. St Paul, MN, USA, Am. Assoc. Cereal Chem. 774 pp.

33) Juliano BO. 1985. Factors affecting nutritional properties of rice protein. Trans. Natl. Acad. Sci. Technol. Philipp.) 7: 205216.

34) Juliano BO and Bechtel DB 1985. The rice grain and its gross composition. In B.O. Juliano, ed. Rice chemistry and technology, 2nd ea., p. 17-57. St Paul, MN, USA, Am. Assoc. Cereal Chem.

35) Juliano BO, Perez CM, Blakeney AB, Castillo T, Kongseree N, Laignelet B, Lapis ET, Murty VVS, Paule CM and Webb BD. 1987. International cooperation testing on the amylose content of milled rice. Starch/Staerke $33: 157$.

36) Juliano BO and B Duff. 1991. Rice grain quality as an emerging research priority in national rice breeding programs. In Rice grain marketing and quality issues, p. 5564. Manila, IRRI.

37) Lacharme M. 2001.Fascicule 6 : La fertilisation minérale du riz. Coopération Française de Développement Rural et de l'Environnement: Direction de la Recherche Formation Vulgarisation. 19p.

38) Lacharme M. 2001. Fascicule 9: Le contrôle de la salinité dans les rizières. Coopération Française de Développement Rural et de l'Environnement: Direction de la Recherche Formation Vulgarisation. 20p.

39) Little RR, Hilder GB and Dawson EH. 1958. Differential effect of dilute alkali on 25 varieties of milled white rice. Cereal Chem., 35 : 111-126.

40) Liu L, Chang E, Fan M, Wang Z and Yang J. 2011. Effects of Potassium and Calcium on Root Exudates and Grain Quality During Grain Filling. Agronomica Sinica, Vol. 37 (4) : 661669.

41) Marschner H. 1995. Mineral Nutrition of Higher Plants. 2ndedn. London, UK: Academic Press. 
42) Mass EV, Lesch SM, François LE and Grieve CM. 1994. Tiller development in salt-stressed wheat. Crop Sci. 34, 1594-1603.

43) Muhammed S, Neue HU and Mendoza BS. 1986. Effects of gypsum on the growth and mineral nutrition of some kefficient rice in coastal saline-sodic soils. Crop Science of the Philippines. Vol. 11 (3) : 213-220.

44) Nangju D and De Datta SK. 1970. Effect of time of harvest and nitrogen level on yield and grain breakage in transplanted rice. Agron. J. 62:468-474.

45) Neue HU, El-Naggar MIA and Rashid M. 1990. Responses and tolerance mechanisms of rice to saline soil conditions. Transactions Vol IV, 50-55.

46) PATRICK RM and HOSKINS FH. 1974. Protein and amino acid content of rice as affected by application of nitrogen fertilizer. Cereal Chem. 51:84-95.

47) Perez CM, Cagampang GB, Esmama BV, Monserrate RU and Juliano BO. 1973. Protein metabolism in leaves and developping grains of rices differing in grain protein content. Plant Physiol. 51 : 537-542.

48) Perez CM and Juliano BO. 1981. Texture changes and storage of rice. J. Texture Studies 12(3): 321-333.

49) Perez CM, Juliano BO, Liboon SP, Alcantara JM and Cassman KG. 1996. Effects of Late Nitrogen Fertilizer Application on Head Rice Yield, Protein Content, and Grain Quality of Rice. Cereal Chem. Vol 73(5):556-560.

50) Pongwichian $P$, Dissataporn $C$, Yamclee $P$, Inthusen $L$, Chueapun K and Wongpiyachon S. 2009. Influence of Salinity on Yields and Grain Quality of Rice Variety of KDML 105.8 pages.

51) Rao PS, Mishra B and Gupta SR. 2013. Effect of Soil Salinity and Alkalinity on Grain Quality of Tolerant, SemiTolerant and Sensitive Rice Genotypes. China National Rice Research Institute. Rice Science Vol 20 (4).

52) Rasouli F, Pouya AK and Karimian N. 2013. Wheat yield and physico-chemical properties of a sodic soil from semiarid area of Iran as affected by applied gypsum. GEODERMA. Vol 193, p. 246-255.

53) SAED. 2011. Manuel Pratique de Riziculture irriguée dans la Vallée du Fleuve Sénégal. SAED, ISRA, AfricaRice. Version 2, 119p.

54) Sartaj IZ, Sirisena DN and Jayawardena DPT. 2001. Varietal response of rice to added nitrogen in terms of grain quality characteristics.

55) Sharma D, Sagwal PK, Singh I and Sangwan A. 2012. Influence of Different Nitrogen and Phosphorus Levels on Profitability, Plant Nutrient Content, Yield and Quality in Basmati Cultivars. International Journal of IT, Engineering and Applied Sciences Research (IJIEASR), Vol. 1, No. 1.

56) Seetanum W and De Datta SK. 1973. Grain yield, milling quality, and seed viability of rice as influenced by time of nitrogen application and time of harvest. Agron. J. 65:390394.

57) Siscar-Lee JJH, Juliano BO, Qureshi RH and Akbar M. 1990. Effect of saline soil on grain quality of rices differring in salinity tolerance. Plant Foods for Human Nutrition, n. 40 : 31-36.

58) Taira H. 1970. Effect of fertilizer on protein content in high yield rice. Nippon Sakumotsu Gakkai Kiji 39:200-203.

59) Taira H, Matsushima S and Matsuzaki A. 1970. Analysis of yield-determining process and its application to yieldprediction and culture development of lowland rice. XCII. Possibility of increasing yield and nutritional value of rice protein by nitrogen dressing. Nippon Sakumotsu Gakkai Kiji 39:33-40.

60) Tabar Y. 2012. Effect of Nitrogen and Phosphorus Fertilizer on Growth and Yield Rice (Oryza Sativa L). Young Researchers Club, Iran Islamic Azad University, sari Branch, sari, Iran. International journal of Agronomy and Plant Production. Vol., 3 (12), 579-584.

61) Unnevehr LJ, Juliano BO, Perez CM and Marciano EB. 1985. Consumer demand for rice grain quality in Thailand, Indonesia, and the Philippines. Manila: International Rice Research Institute. IRRI Res Paper Ser 116. 20 p.

62) Vergara BS. 1984. Manuel pratique de riziculture. IRRI, Philippines. 221p.

63) Wang Q, Zhen R, Ding R, Ding Y, Ji Z, Cao W and Huang P. 2004. Effects of potassium fertiliser application rates on plant potassium accumulation and grain quality of Japonica rice. Scientia Agricultura Sinica. Vol. 37(10) :1444-1450.

64) Xiong F, Wang Z, Gu Y, Chen G, Zhou P. 2008. Effects of nitrogen application time on caryopsis development and grain quality of rice variety yangdao. Jiangsu Provincial Key Laboratory of Crop Genetics and Physiology, Yangzhou University, Yangzhou 225009, China.

65) Yadav GS, Kumar D, Shivay YS and Singh H. 2010. ZincEnriched Urea Improves Grain Yield and Quality of Aromatic Rice. Better Crops/Vol. 94 (2).

66) Yadi R, Dastan S and Yasari E. 2012. Role of Zinc Fertilizer on Grain Yield and Some Qualities Parameters in Iranian Rice Genotypes. Annals of Biological Research. Vol.3 (9):4519-4527

67) Yakan HM, Gürbüz MA, Avsar F, Dürek H, Beser N. 2001. The effect of zinc application on rice yield and some agronomic characters. Chataigner J. (ed.). The new development in rice agronomy and its effects on yield and quality in Mediterranean areas. Montpellier, CIHEAM. Cahiers Options Méditerranéennes, n. 58.

68) Yoshida S, Ogawa M, Suenaga K and He CY. 1983. Induction and selection of salt-tolerant mutant rices by tissus culture techniques for Cereal Crop Improvement. Science Press, Beijing, China / IRRI, Manila, Philippines, pp. 237254.

69) Zhao L, Wu L, Wu M and Li Y. 2011.Nutrient uptake and water use efficiency as affected by modified rice cultivation methods with irrigation. Paddy Water environ, 9: 25-32.

70) Zhu X, Lin L, Shao J and Yang Y. 2008. Effects of Zinc and Chromium Stresses on Quality of Rice Grain. p. 4475 - 4479. Bioinformatics and Biomedical Engineering, The 2nd International Conference, 16-18 May 2008, Shanghai. 
Effects of Amendments in Nitrogen, Phosphorus, Potassium, Zinc and Gypsum on the Quality of the Rice Grain, in Salinity Conditions

Table 1 : list of varieties

\begin{tabular}{|l|l|l|}
\hline $\mathbf{N}^{\circ}$ & Names of varieties & Level of Salinity tolérance \\
\hline V1 & Sahel 108 & Control sensitive \\
\hline V2 & IR 31785-58-1-2-3-3 & Control sensitive \\
\hline V3 & IR 4630-22-2-5-1-3 & Tolerant \\
\hline V4 & IR 59418-7B-21-3 & Tolerant \\
\hline V5 & IR 76346-B-B-10-1-1-1 & Tolerant \\
\hline V6 & IR 72593-B-3-2-3-8 & Tolerant \\
\hline
\end{tabular}

Table 2: list of fertilizers

\begin{tabular}{|c|c|}
\hline $\mathrm{N}^{\circ}$ & Levels of fertilizers \\
\hline $\mathrm{T} 1$ & $0-26-50$ \\
\hline $\mathrm{T} 2$ & $60-26-50$ \\
\hline $\mathrm{T} 3$ & $120-26-50$ \\
\hline $\mathrm{T} 4$ & $150-26-50$ \\
\hline T5 & $0-26-50+$ Zn $\left(10\right.$ kg.ha $\left.{ }^{-1}\right)$ \\
\hline T6 & $60-26-50+\mathrm{Zn}\left(10 \mathrm{~kg} \cdot \mathrm{ha}^{-1}\right)$ \\
\hline $\mathrm{T} 7$ & $120-26-50+\mathrm{Zn}\left(10 \mathrm{~kg} \cdot \mathrm{ha}^{-1}\right)$ \\
\hline $\mathrm{T} 8$ & $150-26-50+Z n\left(10\right.$ kg.ha $\left.{ }^{-1}\right)$ \\
\hline T9 & $0-26-50+$ gypse $\left(100 \mathrm{~kg} \cdot \mathrm{ha}^{-1}\right)$ \\
\hline $\mathrm{T} 10$ & $60-26-50+$ gypse $\left(100 \mathrm{~kg} \cdot \mathrm{ha}^{-1}\right)$ \\
\hline $\mathrm{T} 11$ & $120-26-50$ + gypse $(100$ kg.ha-1) \\
\hline $\mathrm{T} 12$ & $150-26-50+$ gypse $\left(100 \mathrm{~kg} \cdot \mathrm{ha}^{-1}\right)$ \\
\hline
\end{tabular}

Table 3 : Scales of the Standard Evaluation System (IRRI, 1996)

\begin{tabular}{|c|c|c|c|}
\hline Scale & Length & Sharpe & Ratio L/l \\
\hline 1 Extra long & $>7.5 \mathrm{~mm}$ & 1 Slim & $>3.0 \mathrm{~mm}$ \\
\hline 3 Long & entre 6.6 et $7.5 \mathrm{~mm}$ & 3 Average & Between 2.1 and $3.0 \mathrm{~mm}$ \\
\hline 5 Medium & entre 5.5 et $6.6 \mathrm{~mm}$ & 5 Oval & Beteen 1.1 and $2.0 \mathrm{~mm}$ \\
\hline 7 Short & $<5.5 \mathrm{~mm}$ & 9 Round & $<1.1 \mathrm{~mm}$ \\
\hline
\end{tabular}


Effects of Amendments in Nitrogen, Phosphorus, Potassium, Zinc and Gypsum on the Quality of the Rice Grain, in Salinity Conditions

Tableau 4 : Average squares of physico-chemical characteristics of grain of rice varieties in salted and unsalted medium

\begin{tabular}{|c|c|c|c|c|c|c|c|c|c|c|c|c|c|c|c|}
\hline \multicolumn{9}{|c|}{ Axerage square in salted medium } & \multicolumn{7}{|c|}{ Average square in unsalted medium } \\
\hline Source of variation & ddl. & G T. & G. E. & Brisures & P. 100 grains & \begin{tabular}{|c|} 
Longueur \\
(L)
\end{tabular} & $\begin{array}{c}\text { Rapport } \\
\text { (L/) }\end{array}$ & ASV & G.T. & G.E. & Brisures & P. 100 grains & \begin{tabular}{|c|} 
Longueur \\
(L)
\end{tabular} & \begin{tabular}{|c|} 
Rapport \\
(L/)
\end{tabular} & ASV \\
\hline Repetition & 2 & 14.23 & $469.43^{* *}$ & $346.57 * *$ & $0.30 * *$ & $0.82 * *$ & 0.06 & $0.42^{*}$ & 3.38 & 5.98 & 4.57 & 0.01 & 0.32 & $0.25 * *$ & $4.63 * *$ \\
\hline Fertilizer & 11 & $16.15^{*}$ & 59.13 & 28.31 & $0.07 * *$ & $0.18 * *$ & 0.02 & $0.48^{* *}$ & $7.20^{*}$ & 38.22 & $36.56^{*}$ & $0.03^{*}$ & 0.1 & 0.04 & 0.22 \\
\hline Repetition*Fertilizer & 22 & 11.19 & $141.74^{* *}$ & \begin{tabular}{|l|l}
$109.07^{* * *}$ \\
\end{tabular} & $0.17^{* *}$ & $0.15 * *$ & 0.03 & 0.17 & 4.24 & 26.05 & 22.2 & $0.02 *$ & 0.09 & 0.03 & 0.19 \\
\hline Varieties & 5 & $64.98^{* *}$ & $1164.8^{* *}$ & $1007.92^{* *}$ & $2.31 * *$ & $5.27 * *$ & $3.74 * *$ & $42.18^{* *}$ & $73.65^{* *}$ & $1186.21^{* * *}$ & $951.73^{* *}$ & $2.09 * *$ & $3.14^{* *}$ & $3.57^{* *}$ & $40.57^{* *}$ \\
\hline Fertilizer*yarieties & 55 & 6.88 & 30.96 & 23.64 & 0.02 & 0.06 & 0.04 & $0.33^{* *}$ & 3.66 & 28.05 & 25.5 & 0.01 & 0.07 & 0.03 & 0.17 \\
\hline C.V. (\%) & - & 4.47 & 17.03 & 28.23 & 6.93 & 4.36 & 6.45 & 9.86 & 2.93 & 9.36 & 32.09 & 4.81 & 5.26 & 6.57 & 13.49 \\
\hline
\end{tabular}

Table 5 : Mean value of the ASV of varieties studied

\begin{tabular}{|l|c|c|}
\hline Varieties & Mean value of ASV & GT \\
\hline S108 & 3.1 & Intermediate \\
\hline IR31785-58-1-2-3-3 & 3.25 & Intermediate \\
\hline IR4630-22-2-5-1-3 & 3.3 & Intermediate \\
\hline IR59418-7B-21-3 & 3.5 & Intermediate \\
\hline IR72593-B-3-2-3-8 & 4.5 & Intermédiate \\
\hline IR76346-B-B-10-1-1-1 & 5.75 & Low \\
\hline
\end{tabular}

ASV : Alkali Spreading Value

GT : Gelatinization temperature

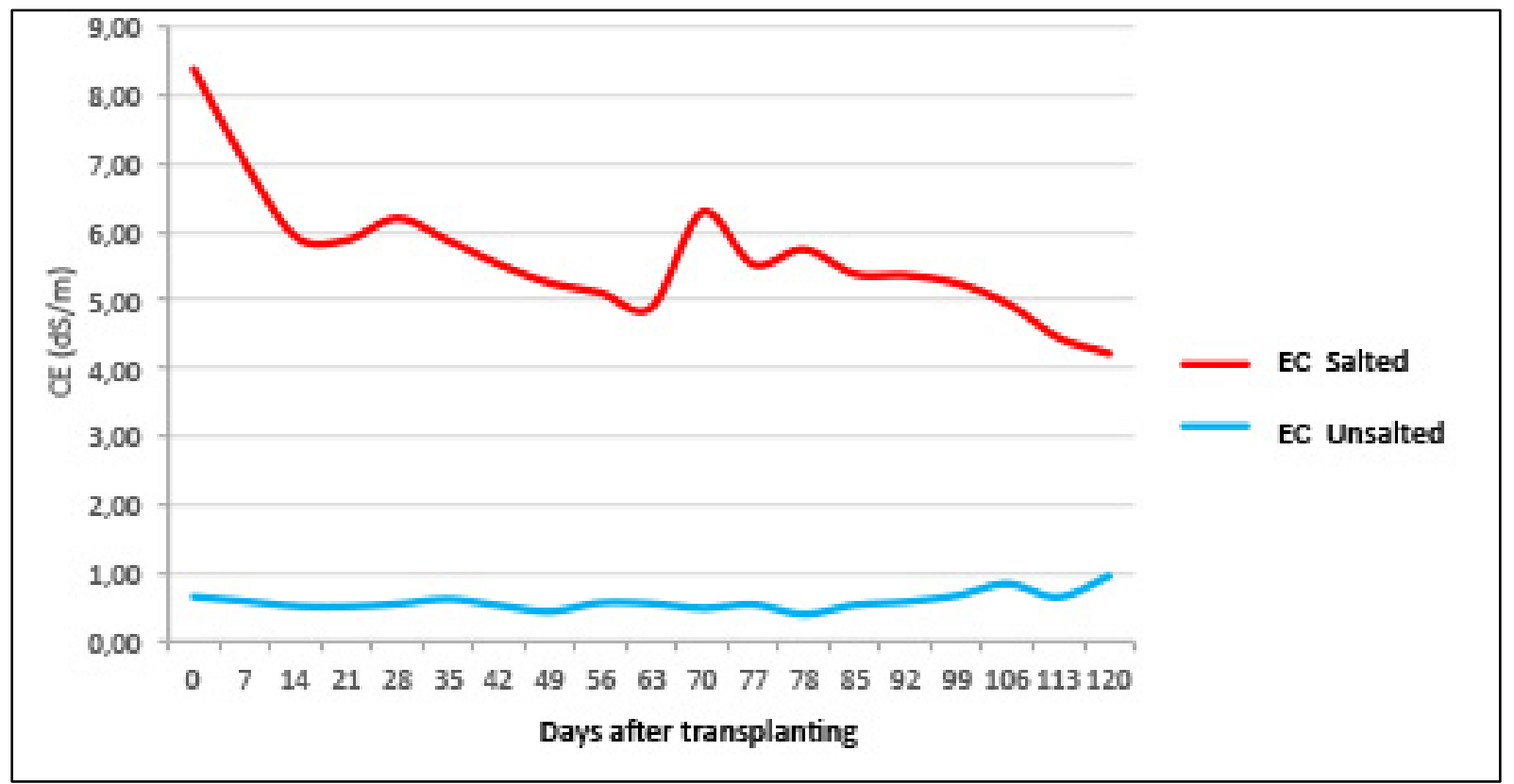

Figure 1 : Evolution of the electrical conductivity in a saltwater environment and unsalted 


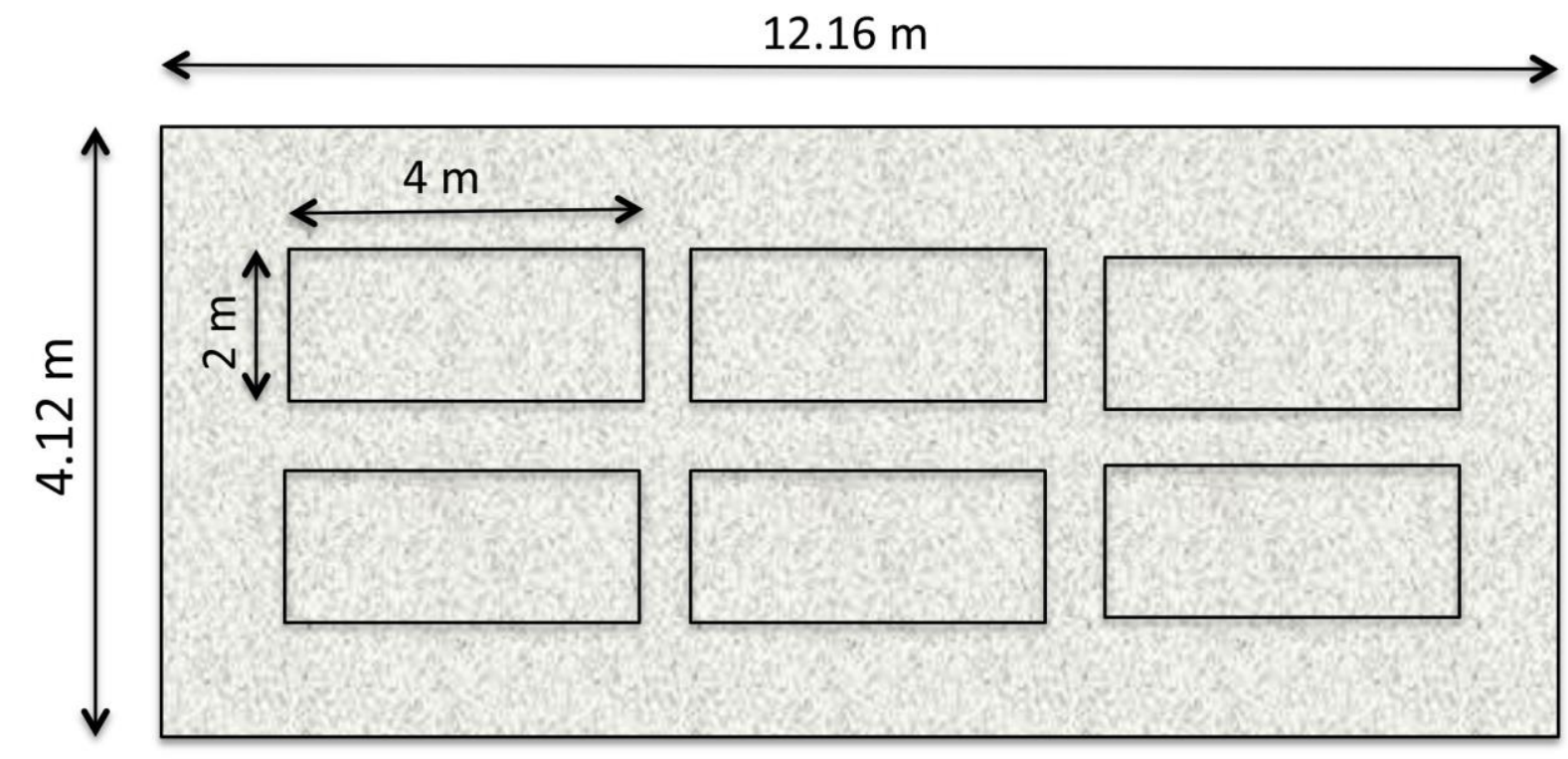

Figure 2 : Single plot 


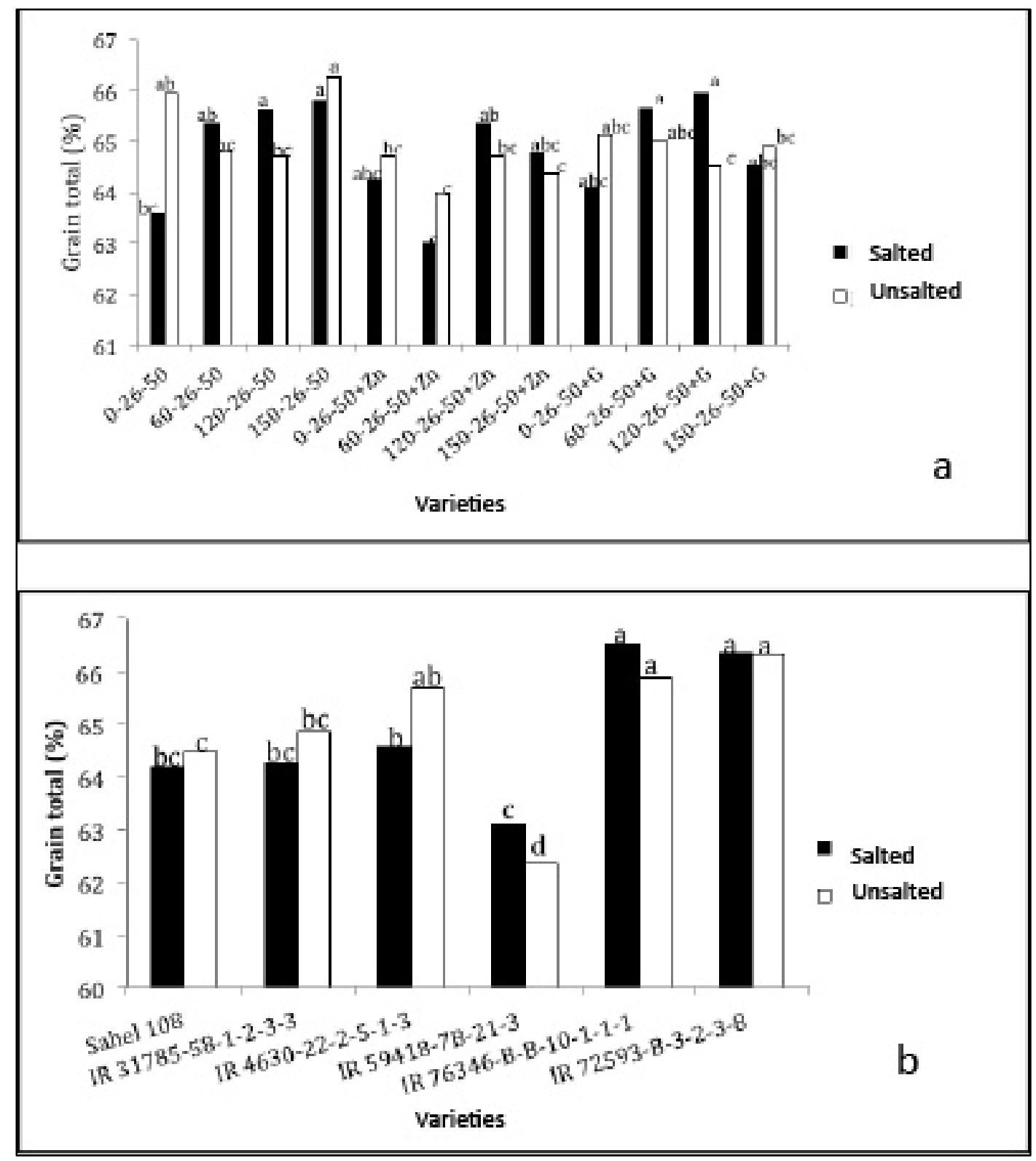

Figure 3 : Comparison of total grain average yield bleached in a saltwater environment and unsalted between combinations of fertilizer (a) and between varieties (b) 


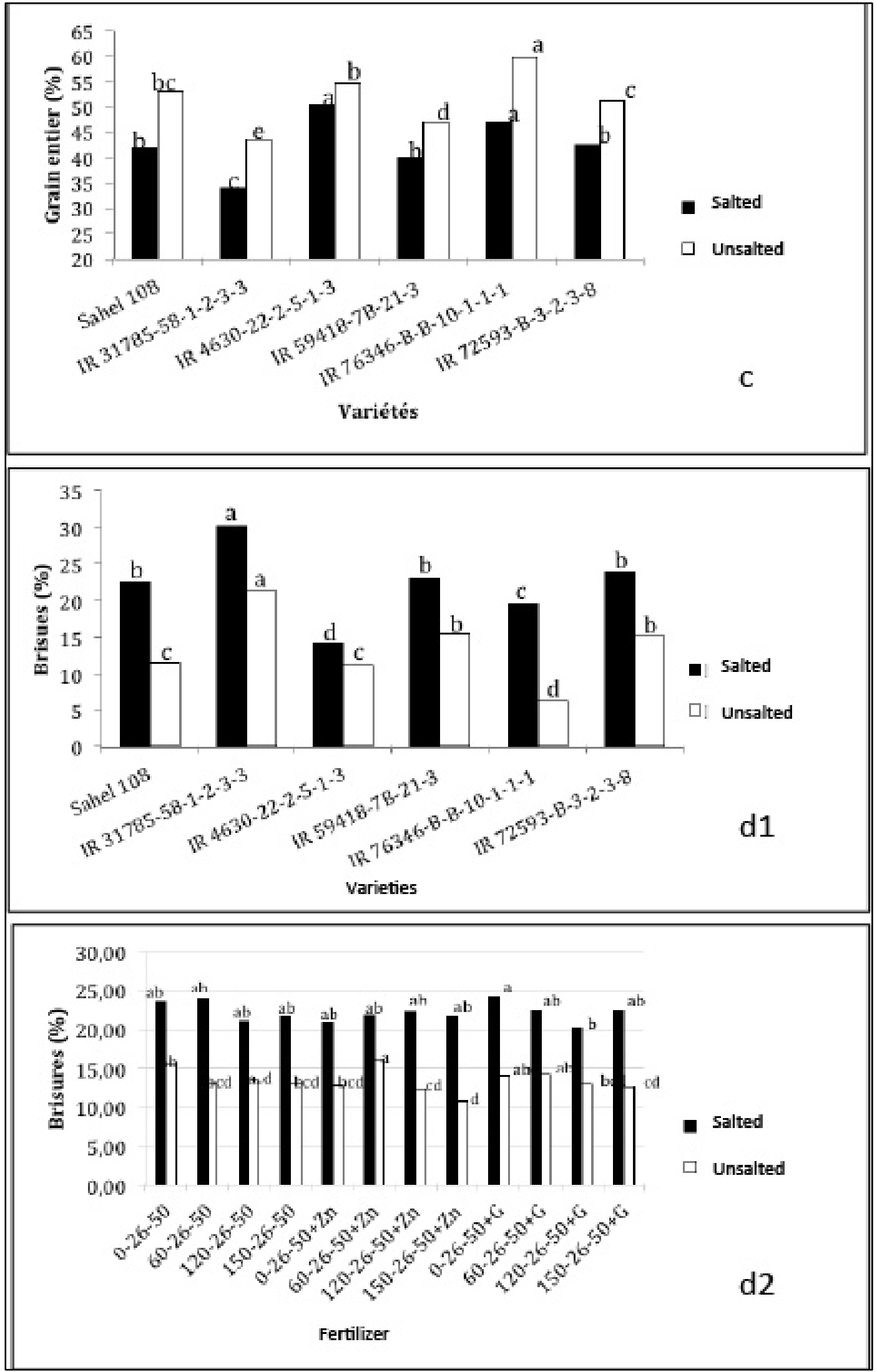

Figure 4: Comparison of average yields in whole grains (c) and broken grains (d1 and d2) in a saltwater environment (MS) and unsalted environment (MNS) between varieties ( $\mathrm{c}$ and $\mathrm{d} 1$ ), and between combinations of fertilizers (d2) 


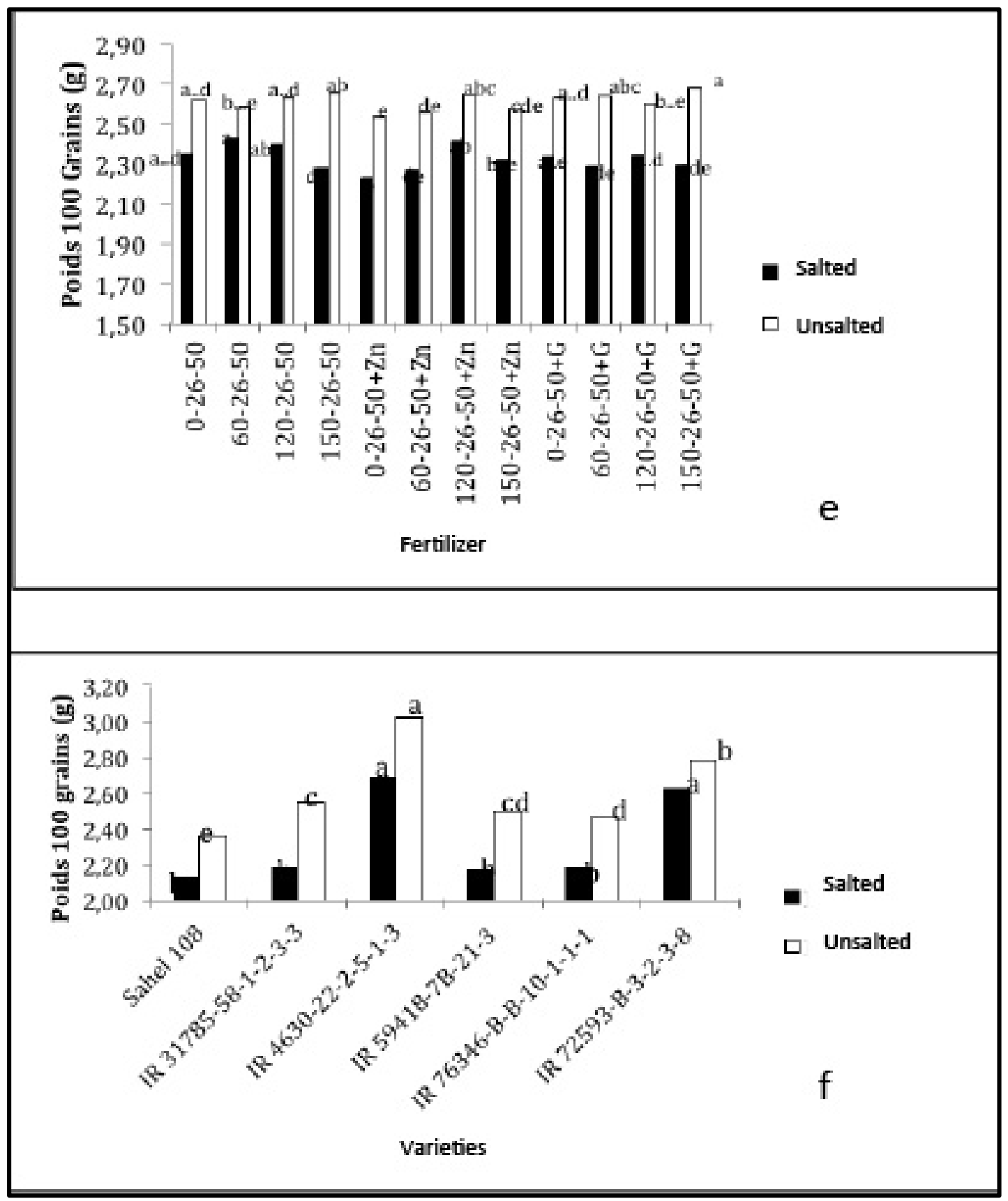

Figure 5 : Comparison of average weight of 100 grains in a saltwater environment (MS) and unsalted environment (MNS) among the combinations of fertilizer (e) and between varieties (f) 


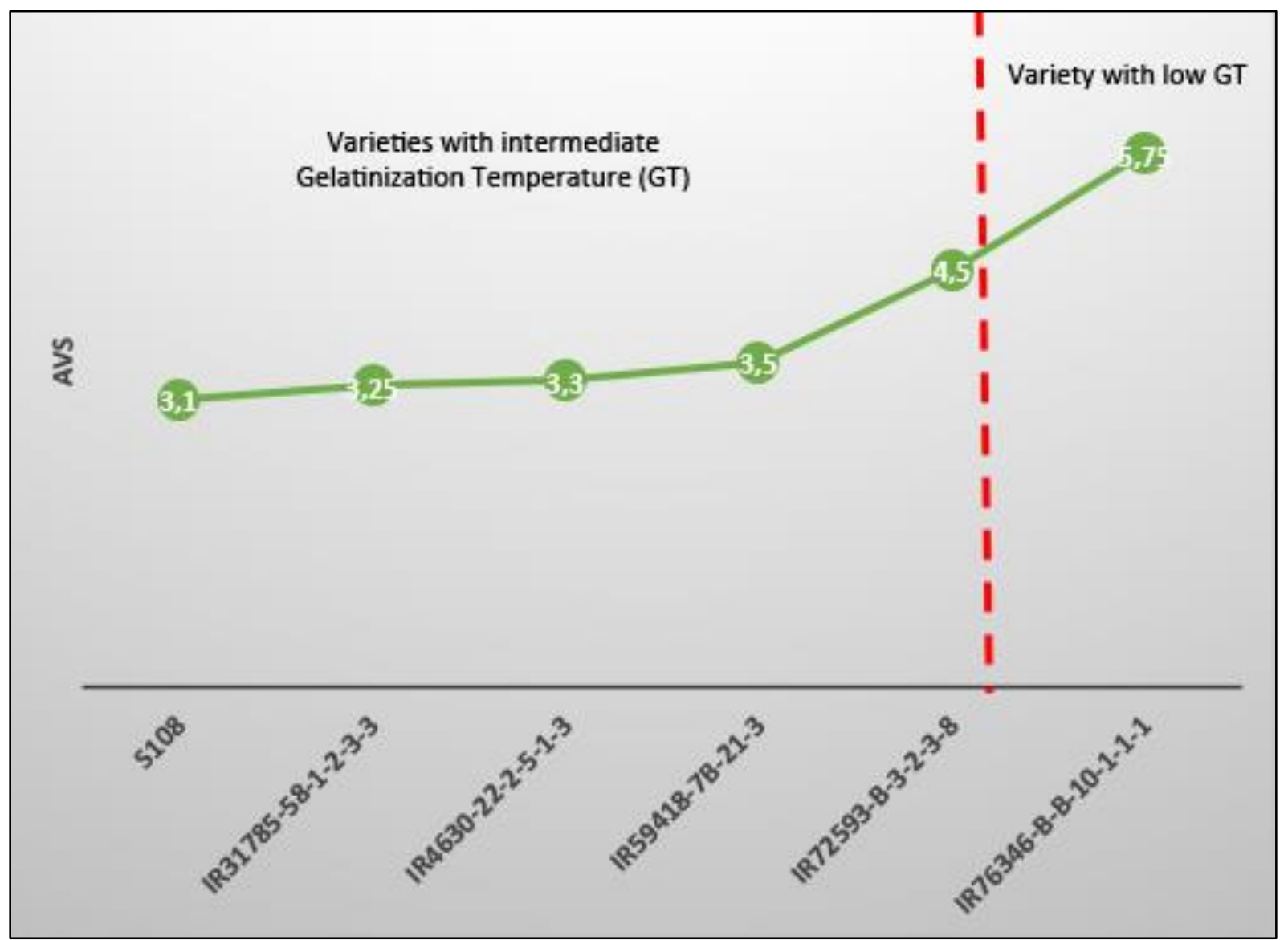

Figure 6 Classification of varieties according to the value of the ASV (Alkaline Spreading Value) 